\title{
Peranan Koperasi Jasa Keuangan Syariah (KJKS) Amanah Mandiri Dalam Meningkatkan Minat Nasabah Terhadap Simpanan Wadi'ah Di Sekarputih Bagor Nganjuk
}

\author{
Juni Iswanto*, Adi Marsono, Agus Thohawi \\ Dosen IAI Pangeran Diponegoro Nganjuk-Jalan Wilis, Kramat, Nganjuk. \\ Email: juniiswanto14@gmail.com
}

\begin{abstract}
Research on the aim of kanggo nyinaoni kanthi using the Amanah Mandiri kanggo sharia service cooperative (KJKS) adds a sense of joy to wadi savings marang. This research uses qualitative research. The research method of the Minangka research method is the research method of sing ana postpositivism, using the kanggo nyalonake babagan natural object, (minangka panemu experiment) where the researcher of the minangka acil is the result of an operational karo. Sharia financial institutions are present in the development of conventional financial institution practices and practices in the Japanese community. Sing diwenehake products by sharia banks may be conventional sing products polished kanthi nerangake contracts with sharia karo relationships. So that the iki thing is actually a negative thing for the public, the yen says sharia, maybe lipstick is just a sharia financial institution.
\end{abstract}

Keywords: Cooperative, Customer Interest, Wadi'ah Savings

\section{PENDAHULUAN}

Seiring dengan perkembangan zaman masyarakat di negara maju dan berkembang sangat membutuhkan lembaga keuangan (bank dan sejenisnya) sebagai tempat untuk melakukan transaksi keuangan. Mereka menganggap bahwa lembaga keuangan (bank dan sejenisnya) merupakan tempat yang aman untuk melakukan berbagai macam aktivitas keuangan baik aktivitas penyimpanan maupun penyaluran dana. Lembaga keuangan memiliki peran yang sangat strategis dan penting dalam perkembangan perekonomian suatu Negara.

Bahkan di era sekarang banyak bermunculan lembaga keuangan (bank) yang berbasis syariah yang tentunya secara operasional berbeda dengan bank konvensional. Salah satu cirri khas koperasi syariah yaitu tidak membebani atau menerima bunga kepada nasabah,akan tetapi menerima atau membebankan bagi hasil serta imbalan lain sesuai dengan akad-akad yang diperjanjikan. Konsep syariah didasarkan Al-Qur'an dan hadist. Semua produk dan jasa yang ditawarkan tidak boleh bertentangan dengan isi AlQur'an dan hadist Rasululloh SAW.1 KJKS Amanah Mandiri adalah satu contoh lembaga keuangan yang berbasis syariah.

Koperasi Jasa Keuangan Syariah (KJKS) “Amanah Mandiri” merupakan Sebuah lembaga keuangan mikro yang menghimpun dana dari anggota dalam bentuk titipan

${ }^{1}$ Ismail , perbankan syariah. Jakarta: Kencana Prenada Media, cetakan 2, 2013, 29 
dengan akad al-wadi'ah yaitu akad antara pihak pertama (penitip) dengan pihak kedua (KJKS), dimana pihak pertama menitipkan dananya kepada pihak kedua, dan pihak kedua selaku penerima titipan untuk dapat memanfaatkan titipan tersebut dalam transaksi yang diperbolehkan oleh islam dan pihak KJKS akan memberikan imbalan berupa bonus untuk tiap bulannya atas dana yang dititipkan pada pihak KJKS. Sedangkan dalam bentuk investasi dengan menggunakan akad al-mudharabah yaitu akad antara pihak yang memiliki dana lebih (shahibul maal) dengan pihak penerima dana (mudharib) yang mana pihak mudharib dapat memanfaatkan dana yang diinvestasikan untuk tujuan tertentu yang sesuai dengan syariah islam. Untuk tercapainya kesejahteraan anggotanya KJKS memberikan pelayanan yang baik bagi anggota dan masyarakat di sekitar KJKS "Amanah Mandiri”. Dalam pelayanannya KJKS “Amanah Mandiri” menawarkan produk simpanan dengan akad wadi'ah dengan sistem bonus tiap bulannya dan produk pembiayaan dengan akad mudhorobah dan murobahah dengan sistem bagi hasil sesuai dengan akad yang disetujui sebelumnya.

Adapun prinsip-prinsip operasional KJKS salah satunya adalah saling tolong menolong seperti yang tertuang dalam Q.S Al-Maidah : 2

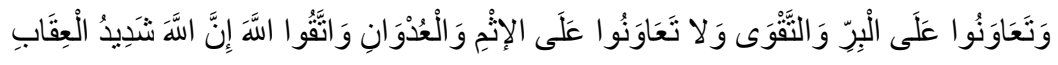

Artinya:

"Dan tolong-menolonglah kamu dalam (mengerjakan) kebajikan dan takwa, dan jangan tolong-menolong dalam berbuat dosa dan pelanggaran. Dan bertakwalah kamu kepada Allah, sesungguhnya Allah amat berat siksa-Nya.” (Q.S. Al-Maidah: 2).2

Koperasi Jasa Keuangan Syariah (KJKS) "Amanah Mandiri” dikembangkan berdasarkan syariah islam yang sistem dan operasionalnya berdasarkan syariah islam yang melarang untuk memungut maupun meminjam uang dengan tambahan bunga (riba), karena sudah jelas diterangkan dalam Al-Qur'an dan hadist bahwa riba jelas haram hukumnya. Al-Qur'an menjelaskan pada (Q.S. Surat Al-Baqarah Ayat : 275) mengenai status riba yang berbunyi :

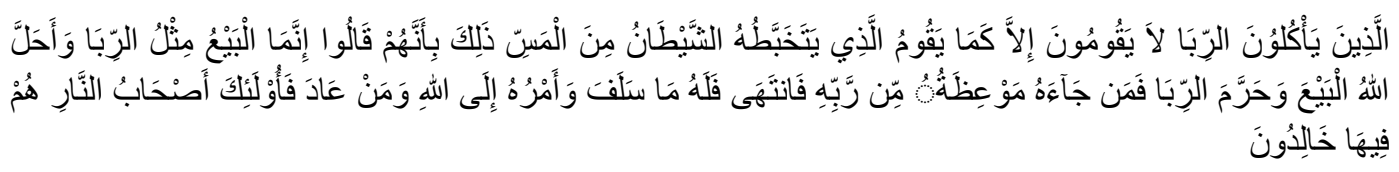

Artinya:

"Orang-orang yang makan (mengambil) riba tidak dapat berdiri melainkan seperti berdirinya orang yang kemasukan syaitan lantaran (tekanan) penyakit gila[. Keadaan mereka yang demikian itu, adalah disebabkan mereka berkata (berpendapat), sesungguhnya jual beli itu sama dengan riba, padahal Allah telah menghalalkan jual beli dan mengharamkan riba. Orang-orang yang telah sampai kepadanya larangan dari Tuhannya, lalu terus berhenti (dari mengambil riba), maka baginya apa yang telah diambilnya dahulu (sebelum datang larangan); dan urusannya (terserah) kepada Allah.

\footnotetext{
${ }^{2}$ H. Ahmad Tohaputra dkk, Al-Qur'an dan Terjemahan, semarang, 2013, 156.
} 
Orang yang kembali (mengambil riba), maka orang itu adalah penghuni-penghuni neraka; mereka kekal di dalamnya." (Q.S. Al-Baqarah Ayat :275).3

Pada prinsipnya KJKS “Amanah Mandiri” adalah Lembaga Keuangan Mikro yang berfungsi sebagai lembaga simpan-pembiayaan modal, yang sumber modalnya dari simpanan dari masyarakat/anggota, para pendiri serta dana pihak ketiga (simpanan, pembiayaan, dana program, lembaga keuangan) yang merupakan dana amanah untuk dikelola, maka pengelolanya harus professional serta berorientasi pada profit (keuntungan). Penggunaan dana inilah yang diberikan kepada para pengusaha kecil, para pedagang dalam bentuk pembiayaan untuk modal usaha, dengan sistem hasil maupun jual beli. Koperasi Jasa Keuangan Syariah (KJKS) "Amanah Mandiri” sebagai sarana masyarakat untuk menginvestasikan dananya di koperasi jasa keuangan syariah (KJKS) “Amanah Mandiri”, berupa simpanan wadi'ah, simpanan berjangka, atau simpanan lainnya. Semua bentuk simpanan mendapatkan bagi hasil atau bonus setiap bulannya.

KJKS "Amanah Mandiri” berangkat dari Gapoktan "Mulya Jaya” yang berdiri tanggal 14 Desember 2009, dengan jumlah anggota 105 orang dan modal yang dimiliki sendiri yaitu; Rp. 16.000.000,- dan hibah dari DEPTAN Rp. 25.000.000,- maka terbentuklah LKMA “Amanah Mandiri” pada tahun 2010, yang diketuai oleh Bapak H. Achmad Sulkan dan manajernya Bapak Puspito dengan jumlah anggota LKMA "Amanah Mandiri" 183 orang dengan berbasis syariah dan mampu mengembangkan modal swadaya dari anggota yang dikelola oleh anggota dan disalurkan lagi pada anggota dengan system Syariah. Sampai sekarang LKMA Unit dari Gapoktan Mulya Jaya Desa Sekarputih Kecamatan Bagor Kabupaten Nganjuk telah berkembang dan mampu membiayai permodalan pada anggota, yang selama ini masih terkendala dalam mengakses permodalan. Betapa tidak, meski baru berdiri tahun awal Januari 2010 Lembaga Keuangan Mikro Agribisnis (LKMA) yang dimiliki Gapoktan Mulya Jaya mampu mengakumulasi modal/aset hampir mencapai Rp 649 juta. Padahal modal awal hasil pengumpulan dari setoran anggota hanya 69 juta rupiah. Namun berkat keuletan dan ketekunan pengelola, baik pengurus Gapoktan maupun manejemen LKMA, membuat LKMA ini bergerak maju dan menjadi solusi bagi anggota Gapoktan Mulya Jaya untuk mengakses modal dengan proses yang mudah dan cepat. 4

Perkembangan LKMA yang bagus tergantung dari pelaksanaan Standar Operasional Prosedur (SOP) dan Standar Operasional Managemen (SOM) yang telah ditetapkan oleh pengurus melalui rapat anggota dan dilaksanakan oleh pengelola yang telah ditunjuk, pelayanan ini yang menjadi dasar bagi pengelola untuk melakasanakan kegiatan keuangan di LKM-A. Misalnya prosedur Simpanan dan Pembiayaan yang mudah dan cepat tapi tetap sesuai dengan Standar Operasional Prosedur (SOP)dan Standar Operasional Managemen (SOM). Namun bukan hanya dalam soal akumulasi modal saja yang menjadi titik keberhasilan LKMA Gapoktan Mulya Jaya ini. Jumlah petani yang mendapat pelayanan permodalan dari LKMA juga amat besar jika dihitung dari masa berdiri LKMA. Satu lagi yang memperlihatkan keberhasilan LKMA ini adalah

\footnotetext{
${ }^{3}$ Ahmad Tohaputra dkk, Al-Qur'an dan Terjemahan, Semarang: 2013, 69.

${ }^{4}$ http://Gapoktan Mulya Jaya Unit LKMA Amanah Mandiri.blogspot.com/ 2011, 02/ Profil LKMA “Amanah Mandiri”/browsing 25 Januari 2016
} 
tingginya kepercayaan masyarakat terhadap LKMA yang mereka kelola. Ini dibuktikan cukup banyaknya nasabah yang tergabung dengan LKMA untuk menabung. Saat ini, ada sekitar 137 orang yang menyimpan dilembaga keuangan milik petani dengan jumlah Rp87.980.000.Produk simpanan yang disediakan cukup beragam. Pengelola tidak terjebak dengan produk-produk simpanan yang biasa disediakan Lembaga Keuangan pada umumnya.

Di tengah-tengah pesatnya pertumbuhan lembaga keuangan syariah masih banyak masyarakat Indonesia yang masih belum mengenal dan memahami tentang sistem operasional lembaga keuangan syariah dalam menjalankan kegiatan bisnisnya hal ini di karenakan lembaga keuangan syariah hadir di tengah-tengah perkembangan dan praktikpraktik lembaga keuangan konvensional yang sudah mengakar dalam kehidupan masyarakat secara luas. Pendapat mereka produk-produk yang di tawarkan oleh bank syariah hanyalah produk-produk bank konvensional yang dipoles dengan penerapan akadakad yang berkaitan dengan syariah. Sehingga hal ini justru memunculkan anggapan negative masyarakat bahwa kata syariah hanya sekedar lipstick dalam lembaga keuangan syariah.

Masih terdapat kebingungan pada karakteristik dasar yang melandasi sistem operasional lembaga keuangan syariah, misalnya pada simpanan wadi'ah (tabungan), terkait bunga yang di tambahkan pada tabungan masih ada keraguan apakah itu berupa bonus apa merupakan bunga yang yang di tambahkan pada tabungan. Hal tersebut apakah berpengaruh terhadap minat masyarakat untuk menabung? karena masyarakat menganggap bahwa pengambilan keuntungan di koperasi syariah sama dengan koperasi konvensional yang menerapkan sistem bunga pada setiap transaksinya.

Dari berbagai polemik yang terurai di atas peneliti tertarik untuk menggali penelitian lebih lanjut yang hasilnya dituangkan dalam bentuk skripsi dengan judul "Peranan Koperasi Jasa Keuangan Syariah (KJKS) Amanah Mandiri Ds. Sekarputih Kecamatan Bagor Kabupaten Nganjuk dalam Meningkatkan Minat Nasabah Terhadap Simpanan Wadi'ah.

\section{METODE PENELITIAN}

\section{a. Pendekatan dan Jenis Penelitian}

Pendekatan adalah metode atau cara mengadakan penelitian seperti eksperimen atua non-eksperimen. Disamping itu juga menunjukkan jenis atau tipe penelitian yang diambil, dipandang dari segi tujuan misalnya eksploratif, deskriptif atau histories. Masih ada lagi pandangan dari subyek penelitiannya, misalnya populasi atau kasus. Penentuan pendekatan ini akan sangat menentukan apa variable atau objek penelitian yang akan ditatap, dan sekaligus menentukan subjek penelitian atau sumber dimana kita akan memperoleh data. ${ }^{5}$ Berdasarkan jenisnya, penelitian ini merupakan penelitian kualitatif. Yang dalam pengerjaannya menggunakan , metode penelitian kualitatif. Metode penelitian kualitatif adalah metode penelitian yang berlandaskan pada filsafat postpositivisme,

${ }^{5}$ Suharsimi Arikunto, Prosedur Penelitian, Suatu Pendekatan Praktik, Jakarta: Rineka Cipta, 2013,64 . 
digunakan untuk meneliti pada obyek yang alamiah, (sebagai lawannya adalah eksperimen) dimana peneliti adalah sebagai instrument kunci, pengambilan sampel sumber data dilakukan secara purposive dan snowbaal, teknik pengumpulan dengan trianggulasi (gabungan), analisis data bersifat induktif/kualitatif, dan hasil penelitian kualitatif lebih menekankan makna daripada generalisasi. ${ }^{6}$ Penelitian ini termasuk penelitian deskriptif analitik yaitu mendeskripsikan objek yang diteliti. Dalam hal ini mengenai peranan lembaga keuangan syariah dalam menarik minat nasabah terhadap simpanan wadiah di Koperasi Jasa Keuangan Syari'ah (KJKS) LKMA "Amanah Mandiri" Nganjuk.

\section{b. Data dan Sumber Data}

Data merupakan hal yang sangat esensial untuk menguak suatu permasalahan, dan data juga diperlukan untuk menjawab masalah penelitian. Adapun jenis data yang digunakan dalam penelitian ini adalah data primer dan sekunder. Data primer adalah data yang bersumber dari informan yang mengetahui secara jelas dan rinci mengenai masalah yang sedang diselidiki. Adapun data primer dalam penelitian ini adalah kata-kata, ucapan dari informan yang berkaitan dengan peranan koperasi syariah dalam meningkatkan kepuasan nasabah. Pemilihan informan dilakukan dengan cara atau teknik snowball sampling, yaitu informan kunci akan menunjuk orang-orang yang mengetahui masalah yang akan diteliti untuk melengkapi keterangan, dan orang tersebut akan menunjuk orang lain lagi bila keterangan yang diberikan kurang memadai dan begitu seterusnya. Adapun yang dimaksud sumber data dalam penelitian adalah subjek dari mana sumber data dapat diperoleh. ${ }^{7}$ Sumber data tertulis berasal dari buku, arsip-arsip KJKS "Amanah Mandiri” Nganjuk yang berkaitan dengan tema penelitian. Sumber foto diambil dari observasi kegiatan yang sesuai dengan tema penelitian.

\section{c. Prosedur Pengumpulan Data}

Pengumpulan Data merupakan suatu proses pengadaan data (primer) untuk keperluan penelitian. Pengumpulan data merupakan langkah yang amat penting dalam metode ilmiah. ${ }^{8}$ Dalam penelitian kualitatif, pengumpulan data dilakukan pada natural setting (kondisi yang alamiah), sumber data primer, dan teknik pengumpulan data lebih banyak pada obervasi berperan serta (participant observation), wawancara, dan dokumentasi. $^{9}$

\section{d. Analisis Data}

Analisis data dalam suatu penelitian merupakan bagian yang sangat penting, karena dengan analisis ini, data yang ada akan disajikan nampak manfaatnya terutama dalam memecahkan masalah penelitian untuk mencapai tujuan akhir penelitian. Bogdan menyatakan bahwa "Analisis data dalah proses mencari dan menyusun secara sistematis

${ }^{6}$ Sugiyono,metode penelitian bisnis, bandung : alfabeta, 2010, 14

${ }^{7}$ Suharsimi arikunto, prfosedur penelitian suatu pendekatan praktik, Jakarta : rineka cipta, 2013,172

${ }^{8}$ Moehar Daniel, Metode Penelitian Sosial Ekonomi, Jakarta: Bumi Aksara, 2003, 133.

9 Boedi Abdullah, Metode Penelitian,Ekonomi Islam;Muamalah, Bandung: Pustaka Setia, $2014,204$. 
data yang diperoleh dari hasil wawancara, catatan lapangan, dan bahan-bahan lain, sehingga dapat mudah difahami, dan temuannya dapat diinformasikan kepada orang lain yang dilakukan dengan mengorganisasikan data, menjabarkannya ke dalam unit-unit, melakukan sintesa, menyusun ke dalam pola, memilih mana yang penting dan yang akan dipelajari, dan membuat kesimpulan yang dapat diceritakan kepada orang lain. ${ }^{10}$ Atas dasar itulah maka analisis data yang dipergunakan dalam penelitian ini adalah analisis deskriptif. Artinya analisis data bukan dengan angka-angka melainkan dalam bentuk katakata, kalimat atau paragraf yang dinyatakan dalam bentuk deskriptif.

e. Pengecekan Keabsahan Data

Dalam metodologi penelitian kualitatif, ada empat criteria berhubungan dengan keabsahan data yaitu Keabsahan konstruk (contruct validity), triangulasi pengamat, triangulasi teori, triangulasi metode, dan keabsahan internal (internal validity).

\section{HASIL DAN PEMBAHASAN}

\subsection{Hasil Penelitian}

a. Koperasi Syariah

\section{1) Pengertian Koperasi Syariah}

Koperasi berasal dari kata cooperation (bahasa Inggris), yang berarti kerja sama. Sedangkan menurut istilah yang dimaksud dengan koperasi adalah suatu perkumpulan yang dibentuk oleh para anggota peserta yang berfungsi untuk memenuhi kebutuhan para anggotanya dengan harga yang relatif rendah dan bertujuan memajukan tingkat hidup bersama. ${ }^{11}$

Pengertian koperasi menurut Mohammad Hatta (1994) "Koperasi didirikan persekutuan kaum lemah untuk membela keperluan hidupnya, mencapai keperluan hidupnya dengan ongkos yang semurah-murahnya, itulah yang dituju. Pada koperasi didahulukan keperluan bersama, bukan keuntungan." 12

Koperasi simpan pinjam syariah didirikan karena Indonesia yang memiliki jumlah penduduk muslim sangat tinggi di sambut oleh pelaku bisnis jasa keuangan syariah. Koperasi Simpan Pinjam Syariah merupakan bentuk koperasi yang telah disahkan oleh Dinas Koperasi dan Usaha Kecil Menengah yang sistem pengoperasiannya kurang lebih sama dengan koperasi konvensional, hanya saja menggunakan konsep syariah atau bagi hasil.

Koperasi Simpan Pinjam Syariah atau Koperasi jasa keuangan syariah disingkat KJKS memiliki dimensi yang berbeda dengan koperasi simpan pinjam konvensional demikian pula jika dibandingkan dengan BMT. Perkembangan ekonomi syariah di Dunia dan juga Indonesia yang notabene memiliki jumlah

\footnotetext{
${ }^{10}$ Sugiyono, Metode Penelitian Manajemen. Bandung: Alfabeta, 2014, 401.

${ }^{11}$ Hendi suhendi, Fiqih Muamalah, Jakarta : Pt. Raja Grafindo Perasda, 2011, 289

12 Suabandi, Ekonomi Koperasi, Teori Dan Praktik, Bandung: Alphabet, 2011, 18
} 
penduduk muslim sangat tinggi di sambut oleh pelaku bisnis jasa keuangan dengan mendirikan bank syariah maupun koperasi syariah.

Secara umum koperasi syariah adalah badan usaha koperasi yang menjalankan usahanya dengan prinsip-prinsip syariah. Sedangakan koperasi jasa keuagan Syariah (KJKS) menurut Keputusan Menteri Negara Koperasi dan Usaha Kecil dan Menengah Republik Indonesia Nomor 91/Kep/IV/KUKM/IX/2004 pada bab 1 tentang ketentuan umum, pasal 1 ayat 2 yang berbunyi:

"Koperasi jasa keuangan yang selanjutnya disebut KJKS adalah koperasi yang kegiatan usahanya bergerak di bidang pembiayaan, investasi dan simpanan sesuai pola bagi hasil (syariah)". ${ }^{13}$

Sedangkan sebagian ulama menyebut koperasi dengan syirkah ta'awuniyah (persekutuan tolong-menolong), yaitu perjanjian kerja sama antar dua orang atau lebih, yang satu pihak menyediakan modal usaha, sedangkan pihak lain melakukan usaha atas dasar profit sharing (membagi untung) menurut perjanjian. Dalam koperasi ini terdapat unsure mudharabah karena satu pihak memiliki modal dan pihak lain melakukan usaha atas modal tersebut.

Nabi Saw juga bersabda, sebagaimana dituturkan Abu Hurairah ra:

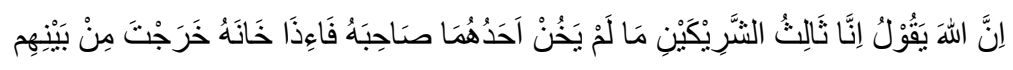

Allah 'Azza wa Jalla telah berfirman: Aku adalah pihak ketiga dari dua pihak yang ber-syirkah selama salah satunya tidak mengkhianati yang lainnya. Kalau salah satunya berkhianat, aku keluar dari keduanya.. (HR. Abu Dawud, al-baihaqi, dan ad-Daruquthni).

\section{2) Prinsip Koperasi Syariah}

Koperasi syariah dalam melaksankan kegiatannya berdasarkan pada prinsipprinsip syariah islam antara lain: ${ }^{14}$

a) Keanggotaan bersifat sukarela dan terbuka

b) Keputusan ditetapkan secara musyawarah dan dilaksanakan secara konsisten dan konsekuen (istiqamah)

c) Pengelolaan dilakukan secara transparan dan professional

d) Pemabagian sisa hasil usaha dilakukan secara adil, sesuai dengan besarnya jasa usaha masing-masing anggota.

e) Pemberian balas jasa modal dilakukan secara terbatas dan professional menurut sistem bagi hasil.

\footnotetext{
${ }^{13}$ http://www.koperasi.net/2015/09/koperasi-simpan-pinjam-syariah.html/ browsing 02 mei 2016

${ }^{14}$ Yahya Abdurhman, Koperasi dalam kacamata Syariah, Bogor, Al-Azhar press, 2011, 27
} 
f) Jujur, amanah, dan mandiri.

g) Mengembangkan sumber daya manusia, sumber daya ekonomi dan sumber daya informasi secara optimal.

h) Menjalin dan menguatkan kerjsama diantara anggota, antar koperasi serta dengan dan atau lembaga lainya.

Ada 7 pantangan yang harus dihindari dalam bisnis. Dan ini harus dipegang sebagai pantangan moral bisnis (moral hazard): 15

a) Maysir yaitu segala bentuk spekulasi judi (gambling) yang mematikan sector riil dan tidak produktif.

b) Asusila yaitu praktik usaha yang melanggar kesusilaan dan norma social

c) Ghoror yaitu segala transaksi yang tidak transparan dan tidak jelas sehingga berpotensi merugikan salah satu pihak

d) Haram yaitu objek transaksi dan proyek usaha yang diharamkan syariah.

e) Riba yaitu segala bentuk distorsi mata uang menjadi komoditas dengan mengenakan tambahan (bunga) pada transaksi kredit atau pinjaman dan pertukaran/barter lebih antar barang ribawi sejenis. Pelarangan riab ini mendorong usaha yang berbasis kemitraan dan kenormalan bisnis, disamping menghindari praktik pemerasan, eksploitasi dan pendzaliman oleh pihak yang memiliki posisi tawar tinggi terhadap pihak yang berpotensi tawar rendah.

f) Ihtikar yaitu penimbunan dan monopoli barang dan jasa untuk tujuan permainan harga.

g) Berbahaya yaitu segala bentuk transaksi dan usaha yang membahayakan individu maupun masyarakat serta bertentangnan dengan maslahat dalam maqashid syariah.

Apabila pantangan-pantangan tersebut dilanggar maka koperasi syariah akan kehilangan identitas (jati dirinya) sebagai koperasi yang berdasarkan pada prinsip syariah. Sebagai suatu badan usaha koperasi syariah memiliki fungsi dan peran sebagai berikut:

a) Membangun dan mengembangkan potensi dan kemampuan anggota pada khususnya, dan masyarakat pada umumnya, guna meningkatkan kesejahteraan sosial ekonominya.

b) Memperkuat kualitas sumber daya insani anggota, agar menjadi lebih amanah, professional (fathonah), konsisten, dan konsekuen (istiqomah) di

${ }^{15}$ Yahya Abdurhman, Koperasi dalam kacamata Syariah, Bogor; Al-Azhar press, 2011, 28 
dalam menerapkan prinsip-prinsip ekonomi islam dan prinsip-prinsip syariah Islam.

c) Berusaha untuk mewujudkan dan mengembangkan perekonomian nasional yang merupakan usaha bersama berdasarkan azas kekeluargaan dan demokrasi ekonomi.

d) Sebagai mediator antara menyandang dana dengan penggunan dana, sehingga tercapai optimalisasi pemanfaatan harta.

e) Menguatkan kelompok-kelompok anggota, sehingga mampu bekerjasama melakukan kontrol terhadap koperasi secara efektif.

f) Mengembangkan dan memperluas kesempatan kerja.

g) Menumbuhkan-kembangkan usaha-usaha produktif anggota. ${ }^{16}$

\section{3) Landasan Koperasi Syariah}

Landasan Koperasi syariah berlandaskan Pancasila dan Undang-Undang Dasar 1945, Koperasi syariah berazaskan kekeluargaan, Koperasi syariah berlandaskan syariah islam yaitu al-quran dan as-sunnah dengan saling tolong menolong (ta'awun) dan saling menguatkan (takaful). ${ }^{17}$

Menurut Undang-undang No 12/1967 tentang Pokok-pokok Perkoperasian, Bab II Pasal 2, mengemukakan bahwa landasan idel koperasi Indonesia adalah Pancasila, landasan structural : Undang-Undang Dasar 1945 dan landasan geraknya; Pasal 33 ayat (1) UUD 1945, beserta penjelasannya; landasan mentalnya: setia kawan dan kesadaran berpribadi.

\section{4) Sumber Permodalan Koperasi Syariah}

Modal koperasi adalah sejumlah dana yang digunakan untuk setiap perkumpulan atau organisasi dalam melakukan kegiatan untuk mencapai tujuannya. Modal koperasi berasal dari modal sendiri maupun pinjaman anggota atau lembaga sesuai dana dengan keperluan lingkup dan jenis usahanya. Dalam mendirikan usaha minimal adalah jumlah anggota pendiri. ${ }^{18}$

Usaha koperasi dilakukan bersama dan dibangun dengan modal bersama. Sumber modal menurut UU No. 12 tahun 1967 pasal 32, yaitu:

a) Modal koperasi terdiri dan dipupuk dari simpanan-simpanan, pinjamanpinjaman, penyisihan-penyisihan hasil usahanya termasuk cadangancadangan dan sumber lain

\footnotetext{
${ }^{16}$ Achmad Solikhin, Buku Pintar Ekonomi Syariah, Jakarta, Pustaka Utama, 2010, 424

${ }^{17}$ Ibid , 525.

${ }^{18}$ http://kementeriankoperasi.com/koperasi-simpan-pinjam-syariah/ browsing 02 mei 2016
} 
b) Simpanan anggota di dalam koperasi terdiri atas simpanan pokok, simpanan wajib, dan simpanan sukarela.

c) Simpanan sukarela dapat diterima oleh koperasi dari bukan anggota.

Sedangkan menurut UU No. 25 tahun 1992 pasal 41, modal koperasi berasal dari modal sendiri (equity capital) dan modal pinjaman (debt capital).

a) Modal sendiri (equity capital) bersumber dari :

(1) Simpanan Pokok, Simpanan pokok merupakan sejumlah uang yang wajib dibayarkan anggota kepada koperasi pada saat masuk menjadi anggota. Besarnya simpanan pokok untuk setiap anggota sama dan tidak dapat diambil selama masih menjadi anggota koperasi.

(2) Simpanan Wajib, Simpanan wajib adalah sejumlah uang tertentu yang wajib dibayarkan oleh anggota kepada koperasi dalam waktu dan kesempatan tertentu, misalnya setiap bulan dengan jumlah yang sama setiapbulannya. Simpana wajib ini tidak dapat diambil oleh anggota selama masih menjadi anggota koperasi.

(3) Simpanan Cadangan, Simpanan sukarela sama seperti simpanan diatas, tetapi dapat diambil sewaktu-waktu. Hibah merupakan sejumlah uang atau barang modal yang dapat dinilai dengan uang yang diterima dari pihak lain yang bersifat pemberian yang tidak mengikat.

b) Modal pinjaman (debt capital) bersumber dari anggota, koperasi lainnya dan/atau anggotanya, bank dan lembaga keuangan lainnya, penerbitan obligasi dan surat hutang lainnya, Sumber lain yang sah.

\section{5) Produk-produk Koperasi Syariah}

a) Pembiayaan dengan Bagi Hasil (Mudharabah)

Fatwa DSN-MUI nomor 07/DSN-mui/iv/2000 menyebutkan bahwa pembiayaan mudharabah adalah pembiayaan yang disalurkan oleh LKS kepada pihak lain untuk usaha produktif. LKS sebagai shahibul maal (pemilik dana) yang membiayai $100 \%$ kebutuhan dana suatu proyek (usaha), sedangkan pengusaha (nasabah) bertindak sebagai mudharib (pengelola usaha). Pembiayaan mudharabah merupakan pembiayaan modal kerja. Keuntungan dibagi di antara mereka sesuai kesepakatan sedangkan kerugian financial hanya ditanggung oleh pemilik dana (PSAK 105 paragraf 04) kecuali jika nasabah (mudharib) melakukan kesalahan yang disengaja, lalai, atau menyalahi perjanjian.

Proporsi bagi hasil usaha mudharabah ditentukan berdasarkan nisbah yang telah disepakati dalam akad. PSAK 105 paragraf 10 menyebutkan bahwa pembagian bagi hasil usaha dapat dilakukan berdasarkan prinsip bagi hasil atau bagi laba (profit sharing). Jika berdasarkan prinsip bagi hasil maka dasar 
pembagian hasil usaha adalah laba bruto (gross profit) buka total pendapatan usaha (omzet), sedangkan jika berdasarkan prinsip bagi laba, dasar pembagian adalah laba neto (net profit) yaitu laba bruto dikurangi beban yang berkaitan dengan pengelolaan dana mudharabah.

Namun demikian, praktik pembiayaan syariah juga masih ada yang menggunakan bagi hasil berdasarkan pendapatan (omzet) untuk kepraktisan dan efisiensi dalam pengendalian. Hanya saja proporsi nisbahnya lebih kecil dari 10 persen. Praktik ini memang praktis ketika nasabah belum memiliki pembukuan yang baik atau pihak shahibul maal belum percaya sepenuhnya terhadap pembukuan yang dibuat oleh mudharib. Pembiayaan mudharabah membutuhkan kepercayaan dan tranparansi yang lebih tinggi mengingat dana sepenuhnya dari pemilik dana. Fatwa DSN-MUI menyebutkan bahwa biaya operasional dibebankan kepada mudharib. Biaya operasional dalam akuntansi dibebankan setelah harga pokok penjualan; akan tetapi, untuk usaha selain perdagangan dan industri maka biaya operasional dapat diartikan dengan operasional utama perusahaan minus selain pajak dan biaya extraordinary.

\section{b) Pembiayaan dengan Musyarakah}

Musyarakah adalah akad kerjasama antara dua pihak atau lebih untuk suatu tertentu, dimana masing-masing pihak memberikan kontribusi dana dengan ketentuan bahwa keuntungan dibagi berdasarkan kesepakatan; sedangkan kerugian berdasarkan kesepakatan kontribusi dana (PSAK 106 paragraf 04) dana tersebut meliputi kas atau asset non kas yang diperkenankan oleh syariah. Asset non kas misalnya emas, perak, perhiasan lain, barang dagangan. Musyarakah merupakan syirkah dalam modal kerja bukan dalm asset modal seperti alat produksi, alat transportasi, dan asset tetap lain. Dalam hal keuntungan perlu bersepakat tetapi kerugian ditanggung proporsional dengan peyertaan dana karena untuk menjalankan usaha dimungkinkan keaktifan antar pihak berbeda. Oleh karena itu, pihak-pihak yang melakukan musyarakah harus cermat, terbuka, jujur, dan setara dalam membuat kesepakatan karena potensi konfliknya relative tinggi.

c) Pembiayaan dengan Murabahah

Murabahah adalah akad jual beli barang dengan harga jual sebesar biaya perolehan ditambah keuntungan yang disepakati dan penjual harus mengungkapkan biaya perolehan barang tersebut secara jujur kepada pembeli (PSAK 105 paragraf 05) baik berdasarkan pesanan maupun tanpa pesanan. Fatwa MUI menyebutkan bahwa jika penjualan barang tersebut menyebabkan kerugian, nasabah tetap harus menyelesaikan hutangnya sesuai kesepakatan awal. Ia tidak boleh memperlambat pembayaran angsuran atau meminta kerugian itu diperhitungkan.

d) Pembiayaan dengan Salam

PSAK 103 mendefinisikan salam adalah akad jual beli barang pesanan (muslam fith) dengan pengiriman di kemudian hari oleh penjual (muslam ilaihi) dan pelunasannya dilakukan oleh pembeli pada saat akad disepakati sesuai dengan 
syarat tertentu. Jika dalam memenuhi pesanan pembeli, penjual juga melakukan pemesanan kepada pihak lain maka hal ini disebut dengan salam parallel. Spesifikasi harga dan barang pesanan disepakati oleh pembeli dan penjual di awal akad. Jaminan dapat diminta untuk menghindari kerugian. Pembiayaan salam adalah pembiayaan modal usaha (kerja) baik kas maupun asset non kas. Beberapa ketentuan pembiayaan salam antara lain: Barang pesanan harus diketahui karakteristiknya secara umum yang meliputi jenis, spesifikasi, teknis, kualitas dan kuantitas. Barang pesanan harus sesuai dengan karakteristik, yang telah disepakati antara pembeli dan penjual. Jika barang pesanan yang dikirimkan salah satu atau cacat maka penjual harus bertanggung jawab. Alat pembayaran harus diketahui jumlah dan bentuknya baik berupa kas atau non kas. Pelunasan harus dilakukan pada saat akad disepakati dan tidak boleh dalam bentuk pembebasan hutang penjual atau penyerahan piutang pembeli dari pihak lain.

e) Pembiayaan dengan Ijarah (Jasa)

Ijarah adalah akad pemindahan hak guna (manfaat) atas suatu barang atau jasa dalam waktu tertentu melalui pembayaran sewa/upah tanpa diikuti dengan pemindahan kepemilikan barang itu sendiri (Fatwa nomor 09/DSN-MUI/IV/2000). Ketentuan obyek ijarah dalam fatwa-MUI diatas meliputi: Obyek ijarah adalah manfaat dari penggunaan barang dan/atau jasa, Manfaat barang harus bisa dinilai dan dapat dilaksanakan dalam kontrak, Pemenuhan manfaat harus yang bersifat dibolehkan oleh syariah, Kesanggupan memenuhi manfaat harus nyata dan sesuai dengan syariah, manfaat harus dikenali secara spesifik untuk menghilangkan ketidaktahuan yang akan mengakibatkan sengketa, Spesifikasi manfaat harus dinyatakan dengan jelas termasuk jangka waktunya.

\section{6) Perbedaan Koperasi Syariah Dengan Koperasi Konvensional}

Perbedaan yang mendasar antara Koperasi Simpan Pinjam Syariah dengan Koperasi Simpan Pinjam Konvensional adalah pada sistemnya, yaitu system bagi hasil dan system bunga. System bagi hasil (mudharobah) telah dicontohkan oleh rasulullah, sedangkan system bunga memberi tambahan bagi pihak kreditur (pihak yang memberikan piutang). Adapun landasan larangan terhadap riba terdapat dalam berbagai ayat salah satunya dalam Al- Qur'an suarat al- baqarah : 275

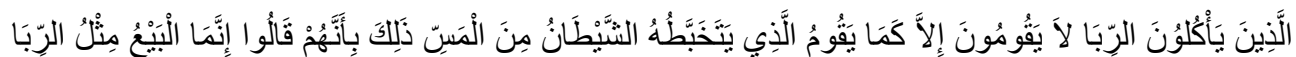

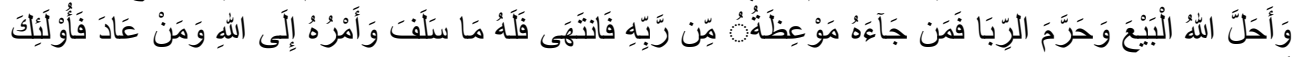

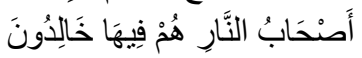

Artinya:

"Orang-orang yang makan (mengambil) riba tidak dapat berdiri melainkan seperti berdirinya orang yang kemasukan syaitan lantaran (tekanan) penyakit gila[. Keadaan mereka yang demikian itu, adalah disebabkan mereka berkata (berpendapat), sesungguhnya jual beli itu sama dengan riba, padahal Allah telah menghalalkan jual beli dan mengharamkan riba. Orang-orang yang telah sampai kepadanya larangan dari Tuhannya, lalu terus berhenti (dari mengambil riba), maka 
baginya apa yang telah diambilnya dahulu (sebelum datang larangan); dan urusannya (terserah) kepada Allah. Orang yang kembali (mengambil riba), maka orang itu adalah penghuni-penghuni neraka; mereka kekal di dalamnya." (Q.S. AlBaqarah Ayat :275).19

Prinsip-prinsipnya pun sama dengan prinsip koperasi umumnya, namun koperasi hanya terdiri dari satu lembaga, yaitu koperasi yang dijalankan dengan sistem Syariah. Dari jenis produknya antara koperasi syariah dan koperasi konvensional sebenarnya hampir sama pada umumnya yang menyangkut produk simpanan dan produk pinjaman. Namun berbeda pada sistem nya, koperasi simpan pinjam syariah kurang lebih seperti bank syariah yang tidak menggunakan sistem bunga seperti koperasi konvensional. Sekalipun Koperasi Simpan Pinjam Syariah hampir sama produknya dengan bank syariah, tapi pada produk funding-nya terdapat perbedaan. Produk funding atau pendanaan pada Koperasi Simpan Pinjam Syariah dinamakan Simpanan sedangkan pada Bank Syariah disebut Tabungan. Perbedaan istilah ini didasari pada induk yang menaungi Koperasi Simpan Pinjam Syariah dan Bank Syariah itu sendiri. Pada Koperasi Simpan Pinjam Syariah berada di bawah naungan Dinas Koperasi sedangkan Bank Syariah dibawah naungan Bank Indonesia dimana izin pendirian kedua jenis lembaga tersebut dikeluarkan dari masing-masing induknya. Terdapat Dewan Pengawas syariah yang dipilih oleh koperasi berdasarkan keputusan dari rapat anggota, dimana dewan ini beranggotakan alim ulama yang ahli persoalan dalam masalah syariah agar dewan pengawas menjalankan fungsi dan tugas sebagai pengawas syariah pada koperasi dan berwenang memberi tanggapan atau melakukan penafsiran terhadap fatwa atau keptusan yang dikeluarkan oleh dewan syariah nasional.

\section{b. Minat Nasabah}

\section{1) Pengertian Minat Nasabah}

Salah satu penentu keberhasilan suatu usaha adalah pelayanan terutama yang bergerak dalam bidang pelayanan umum seperti koperasi. Pelayanan yang baik dan memuaskan akan meningkatkan kepercayaan nasabah terhadap badan usaha tersebut sehingga minat nasabah pun akan meningkat pula.

Para ahli dalam pemasaran mendefinisikan minat nasabah sebagai berikut:20 Menurut Philips Kotler (1995: 711), minat adalah "Di mana minat atau keinginan adalah suatu respon efektif atau proses merasa atau menyukai suatu produk tapi belum melakukan keputusan untuk membeli." Adapun menurut Keith Davis dan Jhon W. Newstron (1993: 66), minat adalah: "Minat atau keinginan merupakan kebutuhan yang telah dimodifikasi oleh lingkungan seseorang atau konsumen".

Lebih lanjut Winardi (1996; 35), Minat adalah "Suatu rangsangan yang datang dan timbul dari hati setelah melihat produk dan jasa yang ditawarkan oleh

${ }^{19}$ Ahmad Tohaputra dkk, Al-Qur'an dan Terjemahan, Semarang: 2013, 69.

20 http://banktheory.blogspot.co.id/2008/12/pengaruh-produk-terhadap-minatkonsumen.html/ browsing 01 mei 2016 
produsen". Adapun Menurut Bambang Hairsoyo (1997:18), minat adalah "Keinginan atau daya tarik yang timbul terhadap suatu barang dan jasa, namun belum terealisasi dengan baik atau nyata".

Dari penjelasan beberapa ahli tersebut dapat ditarik kesimpulan bahwa minat nasabah adalah dorongan kuat bagi nasabah untuk melakukan segala sesuatu dalam mewujudkan pencapaian dan cita-cita yang menjadi keinginannya. Minat yang besar terhadap suatu hal merupakan modal yang besar untuk membangkitkan semangat untuk melakukan tindakan yang diminati dalam hal ini minat nasabah terhadap simpanan wadi'ah yang ada dalam koperasi jasa keuangan syariah (KJKS) Amanah Mandiri.

2) Faktor-faktor Yang Mempengaruhi Minat Nasabah

Ada beberapa faktor yang melatar belakangi timbulnya suatu minat dalam hal ini minat nasabah terhadap koperasi syariah:

a) Konsumsi, tingkat Konsumsi seseorang dengan orang lain tentu berbeda karena pada dasarnya selera manusia satu dengan manusia lain berbeda pula. Tinggi rendahnya daya konsumsi seseorang berhubungan dengan tinggi rendahnya tingkat pendapatan, karena perilaku konsumsi secara psikologis memang berhubungan dengan tingkat pendapatan

b) Pendapatan, Pendapatan atau income adalah penerimaan bersih seseorang, baik berupa uang kontan maupun natura. Apabila pendapatan konsumen tinggi, maka konsumsinya juga tinggi (baik dalam jumlah maupun dalam nilai) karena ini berhubungan dengan pemenuhan kepuasan yang tak terbatas. Sebaliknya apabila pendapatan seseorang rendah maka konsumsi nya juga relatif rendah karena berhubungan dengan keinginan bertahan hidup.

c) Produk atau Jenis Tabungan, Produk koperasi syariah yang beragam, menarik, dan inovatif serta fitur-fitur pendukung/keuntungan yang terdapat dalam produk akan lebih meningkatkan minat nasabah terhadap produk yang ditawarkan.

d) Lokasi, Lokasi yang sangat strategis, aman, gedung yang menarik, nyaman, dan menyenangkan serta fasilitas banyaknya cabang koperasi di berbagai daerah akan menjadi salah satu pilihan bagi nasabah untuk menentukan koperasi yang sesuai dengan pilihan hatinya.

e) Pelayanan, Pelayanan yang cepat, Penampilan menarik, Perlakuan yang ramah menjadi salah satu daya tarik meningkatkan minat nasabah terhadap koperasi syariah.

f) Promosi, Sosialisasi produk dengan menonjolkan manfaat dari suatu produk koperasi Syariah, melalui bahasa komunikasi yang dapat dipahami konsumen. Informasi tentang koperasi syariah bias diaplikasikan dalam 
bentuk brosur dan leaflet maupun di promosikan melaui media cetak dan elektronik.

g) Metode Pengukuran Minat Nasabah, Ada beberapa metode yang digunakan untuk mengadakan pengukuran minat,

3.2 Pembahasan

a. Profil Lembaga

1) Nama Instansi, Alamat, dan Sejarah Berdirinya

KJKS LKM-A "AMANAH MANDIRI" berbadan hukum No. 29/BH/XVI.16./426.101/2010 tanggal 11 Februari 2010 yang beralamat di Jln. Anggrek IV Desa Sekar putih Kecamatan Bagor Kabupaten Nganjuk memiliki total wilayah sekitar 72495 Ha yaitu terdiri dari sawah $43547 \mathrm{Ha}$, pekarangan $27770 \mathrm{Ha}$ dan sisanya masuk pada tanah makam jumlah penduduk 2335 orang terdiri dari laki - laki 1186 dan perempuan 1149 orang sedangkan potensi dari desa dilihat dari sektor pertanian yaitu tanaman padi, tanaman palawija jagung, kedelai dan kacang tanah untuk sektor peternakan dapat diperoleh dengan pemeliharaan sapi, kambing, ayam dan juga lele.

KJKS LKM-A “Amanah Mandiri” berangkat dari Gapoktan "Mulya Jaya” yang berdiri tanggal 14 Desember 2009, dengan jumlah anggota 105 orang dan modal yang dimiliki sendiri yaitu; Rp. 16.000.000,- dan hibah dari Deptan Rp. 25.000.000,- maka terbentuklah LKMA “Amanah Mandiri” pada tahun 2010, yang diketuai oleh Bapak H. Achmad Sulkan dan manajernya Bapak Puspito dengan jumlah anggota LKMA “Amanah Mandiri” 183 orang dengan berbasis syariah dan mampu mengembangkan modal swadaya dari anggota yang dikelola oleh anggota dan disalurkan lagi pada anggota dengan system Syariah. Sampai sekarang LKM-A Unit dari Gapoktan Mulya Jaya Desa Sekar putih Kecamatan Bagor Kabupaten Nganjuk telah berkembang dan mampu membiayai permodalan pada anggota, yang selama ini masih terkendala dalam mengakses permodalan.

\section{2) Visi dan Misi}

Visi: "Menjadi lembaga keuangan mikro yang sehat, berkembang dan terpercaya, yang mampu melayani anggota dan masyarakat lingkungannnya berkheidupan salaam, penuh keselamatan, kedamaian dan kesejahteraan". Adapun misinya adalah:
a) Menyelengarakan pelayanan yang prima kepada anggota.
b) Menjalankan kegiatan jasa keuangan syariah dengan efektif, efisien, dan transparan.
c) Menjalin kersama dengan berbagai pihak.
d) Penghubung antara orang kaya dengan kaum lemah 
b. Peran Koperasi Jasa Keuangan Syariah "Amanah Mandiri” Dalam Meningkatkan Minat Nasabah Terhadap Simpanan Wadi'ah

"KJKS Amanah Mandiri ini pada awalnya berangkat dari Gapoktan Mulya Jaya Desa Sekarputih Kecamatan Bagor Kabupaten Nganjuk yang telah mampu menumbuhkan LKM-A. Lalu pada awal tahun 2010 berganti nama menjadi KJKS “Amanah Mandiri' sampai sekarang, yang mampu mengembangkan modal swadaya dari anggota, dikelola oleh anggota dan disalurkan lagi pada anggota dengan sistem syariah. Selain modal swadya dari anggota KJKS Amanah Mandiri juga mendapatkan modal hibah dari departemen pertanian dimana modalnya disalurkan lagi ke anggota/nasabah dalam bentuk transaksi pembiayaan. Selain dari beberapa sumber dana tersebut KJKS Amanah Mandiri juga mendapatkan sumber modal dari orang kaya yang menitipkan uangnya di KJKS Amanah Mandiri dengan akad yang telah disepakati. Dari dana yang di titipkan tersebut oleh KJKS Amanah Mandiri dimanfaatkan untuk membantu para anggota yang sebagian besar merupakan para petani yang kesulitan dalam megakses modal dengan meminjamkan dana tersebut sesuai dengan akad pembiayaan yang disepakati antara pihak koperasi dengan peminjam tentunya dengan sistem syariah. Pengelolaan yang profesional merupakan kunci utama berkembangnya KJKS Amanah Mandiri ini sehingga dapat berkembang dan bertahan sampai saat ini." ${ }^{21}$

Senada dengan Bapak Puspito, Bapak Erwin selaku bagian pemasaran juga menuturkan :

"Selain dengan pengelolaan yang profesional kami juga membuat inovasi-inovasi produk untuk menarik minat nasabah/anggota. Ada beberapa produk yang kami tawarkan yaitu berupa simpanan dan pembiayaan. Untuk simpanan ada berbagai macam variasi produk, ada simpanan wadi'ah, simpanan idul fitri, simpanan qurban, simpanan mudharabah berjangka, dan simpanan pendidikan. Untuk pembiayaan bisa dengan pembiayaan pertanian, pembiyaan perdagangan, pembayaran listrik online, dan pengadaan pupuk organik". ${ }^{22}$

Berdasarkan ulasan dari Bapak Erwin peneliti tertarik untuk mengulas lebih dalam lagi mengenai simpanan wadi'ah yang ada di KJKS Amanah Mandiri. Peneliti memilih melakukan wawancara pada bapak puspito terkait simpanan wadi'ah di KJKS Amanah Mandiri. Berikut penuturan bapak puspito :

"Berbicara masalah produk antara koperasi syariah dengan koperasi konvensional sebenarnya hampir sama terkait produk simpanan dan produk pinjaman, yang membedakan adalah sistemnya. Koperasi syariah kurang lebih seperti bank syariah yang tidak menggunakan sistem bunga seperti yang ada di koperasi konvensional. Sekalipun antara koperasi syariah dengan bank syariah sama produknya, tapi yang menbedakan adalah produk funding (pendanaanya). Pendanaan pada koperasi syariah dinamakan simpanan, sedangkan dalam bank syariah dinamakan tabungan. Perbedaan istilah tersebut didasari pada induk yang menaungi masing-masing lembaga. Pada koperasi syariah berada di bawah naungan dinas koperasi sedangkan pada banksyariah berada di bawah naungan bank indonesia. Jadi antara simpanan dan tabungan itu sama. Berbicara tentang simpanan

${ }^{21}$ Puspito, Manajer KJKS Amanah Mandiri, Ruang Tamu KJKS Amanah Mandiri, 10 April

${ }^{22}$ Erwin, Pemasaran KJKS Amanah Mandiri, Ruang Tamu KJKS Amanah Mandiri, 10 April 2016 
wadi'ah disini adalah simpanan yang berakadkan wadi'ah. Akad wadi'ah itu adalah akad antara pihak penitip dengan pihak penerima titipan, pihak penerima titipan wajib menjaga dan memelihara barang yang dititipkan dan barang yang dititipkan dapat diambil sewaktuwaktu. Di kjks Amanah Mandiri barang yang dititipkan disini berupa uang. Dalam aplikasinya di kjks Amanah Mandiri ini menggunakan akad wadiah yad dhamanah karena barang yang dititipkan boleh dimanfaatkan sesuai dengan akad yang disepakati kedua pihak. Dan kami selaku pihak penerima titipan akan memberikan imbalan bonus atas dana yang telah dititipkan pada koperasi kami, namun untuk besarnya bonus tidak diperjanjikan sebelumnya. Akan tetapi simpanan yang ada di koperasi syariah tidak dapat berkembang dengan cepat karena tidak adanya LPS (lembaga penjamin simpnan) seperti yang ada di bank syariah hal itu dikarenakan induk yang menaungi masing-masing lembaga berbeda."23

Senada dengan penuturan Bapak Puspito, Bapak Syafi'i selaku karyawan bagian pembukuan KJKS “Amanah Mandiri” menuturkan sebagai berikut :

"Dari data yang diambil pada tahun 2015 dari 638 anggota / nasabah baru 193 anggota/nasabah yang sadar akan pentingnya menabung jika di prosentase hanya 30,2\% saja. Hal ini menunjukkan bahwa kesadaran masyarakat akan pentingnya menabung masih sangat kurang sehingga masih perlu dorongan dan motivasi dari berbagai pihak supaya masyarakat mau dan terbiasa untuk menabung. dari keseluruhan anggota yang menabung mayoritas penabung bukanlah berasal dari kalangan petani namun dari profesi lain sedangkan mayoritas anggota/nasabah yang ada di kjks Amanah Mandiri merupakan petani sehingga dari lembaga kami perlu mengoptimalkan memotivasi dan mendorong anggota/nasabah khususnya para petani untuk mau dan terbiasa menabung." 24

Setelah mengetahui ulasan dari bapak Syafi'i, maka selanjutnya bapak puspito akan melanjutkan ulasan mengenai peran KJKS Amanah Mandiri dalam meningkatkan minat nasabah. Berikut penuturan bapak Puspito:

"Terkait meningkatkan minat nasabah KJKS memiliki peran yang sangat penting, beberapa peran tersebut di antaranya: (1) dari sisi pengelolaan dana, pengelola harus profesional dalam mengolah semua dana dari berbagai sumber serta penyaluran dana yang tepat sasaran demi tercapainya tujuan bersama (anggota), (2) sebagai penghubung antara yang kaya dengan yang miskin, yang dimaksud penghubung yang kaya dengan yang miskin disini adalah pihak yang kelebihan dana/ uang (orang kaya) akan menitipkan uangnya pada koperasi oleh koperasi dana ynag dititipkan akan di salurkan pada pihak yang tidak memiliki dana ( oramg miskin) dengan melalui produk pembiyaan. (3) koperasi syariah menjadi lembaga tidak hanya berorientasi kepada profit tetapi juga bergerak di bidang sosial (penyaluran ZIS), maksudnya disini adalah pihak koperasi mengambil keuntungan tidak semata untuk koperasi saja namun dari sebagian keuntungan tersebut di salurkan pada warga yang tidak mampu melalui kegiatan sosial berupa penyaluran zakat dengan dititipkan pada lembaga amil zakat terdekat. (4) melayani anggota / masyarakat yang kesulitan dalam mengakses permodalan ke perbankan, pada umumnya masyarakat pedesaan enggan untuk meminjam modal ke perbankan dikarenakan berbagai hal salah satunya persyaratan yang sangat banyak dan pecairan dana yang cukup lama bahkan berhari-hari, selain itu letak perbankan yang cukup jauh karena kebanyakan berada di perkotaan sehingga masyarakat yang tidak memiliki akomodasi ke kota sulit mendapatkan modal sehingga masyarakat pedesaan tidak bisa berkembang dalam menjalankan usahannya. (5) Sebagai motivator yang membantu dan mendorong menumbuhkan kesadaran pada diri anggota/masyarakat tentang pentingnya menabung, dengan selalu memotivasi dan mendorong nasabah untuk menabung maka lama kelamaan kesadarn akan pentingnya menabung akan tumbuh dalam

${ }^{23}$ Puspito, Manajer KJKS Amanah Mandiri, Ruang Tamu KJKS Amanah Mandiri, 10 April 2016

24 Syafi'i, Pembukuan KJKS Amanah Mandiri, Ruang Tamu KJKS Amanah Mandiri, 10 April 2016 
diri anggota/nasabah mengingat menabung merupakan kegiatan yang sangat penting untuk masa depan. (6) sebagai sarana pemberdayaan masyarakat melalui pelatihan - pelatihan dan pendampingan sehingga SDM pengelola dan anggota semakin berkembang. Mengingat letak kjks Amanah Mandiri yang berada di pedesaan yang mayoritas merupakan petani serta sdmnya masih sanagat minim sehingga pelatihan - pelatihan pertanian sangat membantu dalam keberhasilan para anggota." 25

Dari pemaparan bapak Puspito, bapak Erwin, dan bapak Syafi'i di atas dapat peneliti analisis bahwa peran KJKS “Amanah Mandiri” sangat penting baik dari sisi pengelolaan, inovasi-inovasi produk serta pengklasifikasian nasabah terutama dealam meningkatkan minat nasabah terhadap simpanan wadi'ah mengingat kesadaran untuk menabung anggota/masyarakat Ds.Sekarputih masih kurang terutama pada kalangan petani mengingat mayoritas nasabah/anggota kjks Amanah Mandiri berprofesi sebagai petani sehingga perlu dorongan dan motivasi dari KJKS Amanah Mandiri selaku lembaga keuangan yang berbasis syariah yang ada di ds.sekarputih kecamatan bagor kabupaten nganjuk yang menjadi sarana masyarakat dalam mengakses permodalan.

Strategi koperasi jasa keuangan syariah "Amanah Mandiri” dalam meningkatkan minat nasabah terhadap simpanan wadi'ah, Setelah mengetahui peran penting KJKS Amanah Mandiri dalam meningkatkan minat nasabah terhadap simpanan wadi'ah, peneliti ingin melanjutkan penelitian mengenai strategi KJKS Amanah Mandiri dalam meningkatkan minat nasabah terutama terhadap simpanan wadi'ah. Berikut pemaparan Bapak Puspito Manajer KJKS Amanah Mandiri :

"Suatu lembaga keuangan baik konvensional maupun syariah memerlukan strategi yang pas dalam pengembanganya supaya dapat bersaing dengan koperasi-koperasi lain dan tetap dapat melayani anggotannya dalam kegiatan simpan pembiayaan. Masing-masing lembaga keuangan menggunakan strategi yang berbeda-beda dalam pengembangannya tergantung pada kebijakan masing-masing lembaga pengelola. Beberapa strategi yang ada di KJKS Amanah Mandiri yaitu dengan memberikan pelayanan yang baik, transparan, dan bertanggung jawab sehingga nasabah merasa nyaman dan aman apabila akan menitipkan ataupun akan meminjam dana dari koperasi. Selain itu dari pengelola akan memberikan penjelasan atau konsultasi tentang keutamaan produk simpanan wadi'ah (keutamaan menabung di KJKS Amanah Mandiri). Tidak hanya di kantor para pengelola akan mensosialisasikan keutamaan produk simpanan wadi'ah pada simbol-simbol masyarakat, misalnya pada kelompok yasinan, ibu-ibu muslimat, dan pada simbol - simbol yang lain Bapak Puspito menyebut strategi ini dengan istilah menjemput bola. Pemberian bonus/jasa terhadap simpanan yang di titipkan di koperasi menjadi salah satu daya tarik utama masyarakat. Pengelola yang Pro aktif dalam melayani simpanan (menjemput dan mencairkan tabungan di rumah nasabah) sangat membantu masyarakat/anggota. Pendampingan yang dilakukan pengelola terhadap usaha anggota dalam mengelola usahanya semakin menambah daya tarik KJKS "Amanah Mandiri"dalam melayani anggota/nasabahnya."26

Bapak Erwin selaku bagian pemasaran menambahkan bahwa :

\footnotetext{
${ }^{25}$ Puspito, Manajer KJKS Amanah Mandiri, Ruang Tamu KJKS Amanah Mandiri, 10 April 2016

${ }^{26}$ Puspito, manajer KJKS Amanah Mandiri, ruang tamu KJKS Amanah Mandiri, 02 Mei 2016
} 
"Untuk menarik minat nasabah kuncinya adalah dalam pelayanannya, dengan pelayanan yang ramah sudah pasti nasabah akan merasa senang, sehingga nasabah mudah tertarik terhadap produk yang ditawarkan, dalam menarik nasabah tidak melulu harus mensosialisasikan di kantor mengingat mayoritas nasabah koperasi kami para petani maka dalam mensosialisasikan/mempromosikan produk kebanyakan sambil minum kopi di warung-warung warga, sambil ngobrol-ngobrol santai sehingga nasabah merasa nyaman dengan situasi yang tidak formal, sehingga kami sebagai karywan bagian pemasaran harus pintar-pintar mengkondisikan situasi sesuai dengan kondisi nasabah kami."27

Berdasarkan pemaparan di atas peneliti menganalisis bahwa strategi yang tepat seperti melayani dengan baik, transparan, dan bertanggung jawab, pensosialisasian mengkondisikan dengan warga, pro-aktif dalam melayani nasabah akan meningktkan minat nasabah terhadap produk yang di tawarkan serta lembaga pun dapat berkembang dan terus bersaing dengan yang lainnya.

\section{KESIMPULAN}

a. Peran KJKS Amanah Mandiri dalam meningkatkan minat nasabah yaitu (1) mengelola dana dengan profesional, (2) menghubungkan antara yang kaya dengan yang miskin, (3) bergerak di bidang sosial (penyaluran ZIS), (4) melayani anggota / masyarakat yang kesulitan dalam mengakses permodalan ke perbankan, (5) memotivasi dan mendorong gemar menabung, (6) sarana pemberdayaan masyarakat

b. Strategi KJKS Amanah Mandiri dalam meningkatkan minat nasabah terhadap produk simpanan wadi'ah yaitu (1) pelayanan yang baik, transparan, dan bertanggung jawab. (2) pemberian konsultasi produk-produk. (3) Mensosialisasikan produk simpanan wadi'ah pada simbol-simbol masyarakat. (4) Memberikan bonus/jasa terhadap simpanan yang di titipkan di koperasi. (5) Pro aktif dalam melayani simpanan. (6) Pendamping terhadap usaha anggota dalam mengelola usahanya.

c. Dalam pembuatan inovasi-inovasi produk dan pembuatan kebijakan pihak koperasi perlu mengklasifikasikan nasabah untuk terwujudnya tujuan bersama terutama pada sektor agribisnis karena mayoritas anggota/nasabah berasal dari kalangan petani dan pedagang. Selain itu dengan diklasifikasikan nya nasabah pihak koperasi akan lebih mudah untuk mengoptimalkan pensosialisasian produk pada obyek yang dituju dalam hal ini adalah anggota/nasabah.

\section{UCAPAN TERIMA KASIH}

Untuk dapat menyelesaikan penelitian ini, penulis mendapatkan berbagai bantuan dari beberapa pihak. Oleh karena itu penulis berkewajiban menyampaikan rasa terima kasih sedalam-dalamnya, terutama kepada Rektor Institut Agama Islam Pangeran Diponegoro (IAI PD) Nganjuk yang telah memberikan izin kepada penulis untuk dapat melakukan kegiatan penelitian ini, Dekan Fakultas Syariah dan

\footnotetext{
${ }^{27}$ Erwin, Pemasaran KJKS Amanah Mandiri, Ruang Tamu KJKS Amanah Mandiri, 02 Mei 2016
} 
Ekonomi Islam, yang telah memberikan izin dan pengarahan pada penulis serta tak lupa pada rekan-rekan seperjuangan yang telah mensuport adanya penelitian ini, semoga apa yang telah mereka diberikan balasan setimpal dari Allah Swt.

\section{REFERENSI}

Achmad Solikhin, Buku Pintar Ekonomi Syariah, Jakarta, Pustaka Utama, 2010, 424

Ahmad Tohaputra dkk, Al-Qur'an dan Terjemahan, Semarang: 2013, 69.

Hendi suhendi, Fiqih Muamalah, Jakarta : Pt. Raja Grafindo Perasda, 2011, 289

http://banktheory.blogspot.co.id/2008/12/pengaruh-produk-terhadap-minatkonsumen.html/ browsing 01 mei 2016

http://Gapoktan Mulya Jaya Unit LKMA Amanah Mandiri.blogspot.com/ 2011, 02/ Profil LKMA “Amanah Mandiri”/browsing 25 Januari 2016

http://kementeriankoperasi.com/koperasi-simpan-pinjam-syariah/ browsing 02 mei 2016 http://www.koperasi.net/2015/09/koperasi-simpan-pinjam-syariah.html/ browsing 02 mei 2016

https://akarbk.wordpress.com/2011/07/25/metode-pengukuran-minat/ browsing 01 mei 2016

Ismail , perbankan syariah. Jakarta: Kencana Prenada Media, cetakan 2, 2013, 29

Nizarul Alim, Pembiayaan Syariah untuk usaha mikro dan kecil, Surabaya; bina ilmu, 2009, 5-10

Suabandi, Ekonomi Koperasi, Teori Dan Praktik, Bandung: Alphabet, 2011, 18

Yahya Abdurhman, Koperasi dalam kacamata Syariah, Bogor, Al-Azhar press, 2011, 27 